\title{
Multicultural Education Based on Local Wisdom as an Alternative Values Education in Early-Childhood Education
}

\author{
Nurdinah Hanifah \\ Universitas Pendidikan Indonesia Kampus Sumedang \\ Corresponding e-mail: nurdinah.hanifah@upi.edu
}

\begin{abstract}
Education today is focused on the goal to establish intelligence, knowledge, personality and intelligence of children in an atmosphere of globalization, on that matter learning activities should directly engage learners with real life by then they will not be isolated and prepared for rapid changes in society. The importance of values' education to be something that cannot be avoided. Values' educations are long-term standards that help a person determine how they should approach a situation or person, which makes it an important component of determining how the future culture interacts and acts. Providing an education on values at a young age can ensure that they are guided by these principles throughout life challenges of education in Indonesia is the impact of globalization, including the heterogeneity of society, the degradation of moral values, and reduced mutual respect. Therefore, we need a new paradigm of education that is ready to face the conditions of social and cultural diversity of Indonesia. Paradigm is meant integrating local wisdom in multicultural education. Local wisdom is needed because Indonesia is a country full of diversity, which is the capital of culture born from the wealth of local knowledge (local wisdom). Through multicultural education based on local wisdom children's awareness to the importance of respecting other people, and different cultures will be nurtured. This article outlines how the development of multicultural education based on local wisdom in learning activities in early-childhood education.
\end{abstract}

Keywords: multicultural education, local wisdom, value education

\section{INTRODUCTION}

The era of globalization is a necessity that will be passed by anyone who lives in this XXI century, have an impact on the demand to have a number of competencies that will determine the quality of human resources. In this case Indonesia should be prepared. Sumaatmadja (2001, p. 6) said "in the era of globalization characterized by increasingly intense competition, lack of information, strong communication and openness". Indonesia is affected by globalization which causes a lot of problems. It is therefore necessary the educational programs are applied as early as possible to cope with the impacts of globalization. Mursid (2016, p. 3) describes "Early-childhood education is provision of education that focuses on laying the foundation toward growth and physical development (Psychomotor coordination), intelligence (thinking skills, creativity, emotional intelligence, spiritual intelligence), social emotional (attitudes, behavior and religion), language and communication, based upon the specific and the stages of early-childhood development". Education at this stage focuses on Physical intelligence/cognitive, emotional, and social education (Sujiono, 2009, p. 139). In addition the importance of early-childhood education is expressed by Papalia and Olds (2009, p. 213),“... a good preschool is considered to be one that stimulates children's development in all domainphysical, social, emotional, and cognitive through active interaction with teachers, other children, and carefully chosen materials". It is clear that through early-childhood education, can stimulate the development of students in all aspects, both physical, social, emotional, and intellectual, through active interaction with teachers, the interaction students with students, and also through learning materials that have been prepare. Talk about the purpose of early-childhood education is expressed by Solehudin (1997) that the purpose of earlychildhood education is to facilitate the growth and 
development of children in optimal and thoroughly in accordance with the norms and values of life espoused. Suyadi (2015, p. 144) also outlines about the purpose of early-childhood education, which is to guide all natures that exist in the child so that he as a member of the public can reach the safety and happiness of the highest in life.

Through early-childhood education can develop all its potential, ranging from potential intellectual (cognitive), social, emotional and physical-motor. In addition to the aspects that should not be left out is the development of a sense of religion, practices or behaviors that are expected to master a number of knowledge and basic skills in accordance with the needs and development levels and motivation and positive learning attitude. concerning social development, Mursid (2016, p. 50) defining social development is an achievement of maturity in social relations, social development can also be defined as the process of learning to conform norms of groups, morals and traditions; merge themselves into one entity and communicate and respect with each other. The orients of education overemphasize cognitive aspects and ignore the aspect of personality (which is more important), should be changed.

Education is a conscious and deliberate effort to develop one's ability to be better in various aspects of knowledge, understanding and personality to be useful to himself and the surrounding environment, this opinion is in line with what was stated by Muhibbinsyah (2014, p. 10) that "education can be defined as a process with certain methods so that people acquiring the knowledge, understanding and how to behave in conforming with the needs."

Based on the explanation above it can be concluded that education is a conscious effort and planned to change a person's behavior for the better by using certain methods to shape the personality self, developing the abilities it has, and skills on students according with the needs in the community.

Wave of globalization has eliminated the boundaries of space supported by information technology that destroys the boundaries of a state of Indonesia as a nation state a diversified have special problems associated with maintaining and developing the Indonesian people who bhinneka considering Indonesia is one of the largest multicultural world, the truth of this statement can be seen from the socio-cultural and geographical so diverse and wide. Being multicultural is inevitable in Indonesia, and diversity is national identity. Diversity phenomenon, actually, it stated on national symbol "Bhineka Tunggal Ika" (it meant "Unity and diversity").

Multicultural education is a process that provides awareness of living together in diversity in the social, economic, and culture by instilling the values of tolerance, empathy, sympathy, and social solidarity in society. Indonesia faced with identical critical because globalization continuously erode the values of national identity Indonesia. In my view, being multicultural is inevitable in Indonesia, and that is national identity. We life in a diverse community. Multicultural education emerged from diverse courses, programs and practices. The multicultural educational system devise the educational institution to respond demands, needs and aspirations of the various groups of students (Bank, 2010, P.7).

Considering the importance of the understanding of cultural diversity in Indonesia, the multicultural education need to look for ways to remain internalized in the public soul. One way to do is to provide multicultural education since the beginning of early childhood so that it can become a solid foundation for the development of children's souls. multicultural education as perspective that recognizes the reality of the social, political, and the economy experienced by each individuals in meeting human complex and diverse culture, and reflects the importance of culture, race, sexuality and gender, ethnicity, religion, status social, economic, and exclusions in the educational process. Through learning based multicultural, students are expected not cut off from their cultural roots, and apparently whether acknowledged or not multicultural education highly relevant in practice in a democracy as it is today.

When education is given the responsibility to maintenance the values and abilities of the students, it is not the only aspect of knowledge (cognitive) that must be developed, but aspects of attitudes (affective) and skills (psychomotor) should also be developed when the Teaching and Learning Activities in progress. The third aspect is a very important part to change human behavior for the better and become a man of quality of all aspects of knowledge and moral as disclosed by Hernawan, dkk (2010, p. 6) that "changes in behavior as a result of learning to be grouped in three domains (department), namely: knowledge (cognitive), motor skills (psychomotor) and control values or attitudes (affective)".

This article aims to describe how multicultural education based on local wisdom as an alternative educational value. 


\section{LITERATURE REVIEW}

\subsection{What Is Local Wisdom?}

Umar, (2003) explains that local genius is term used by anthropologist referring to certain communities or cultures that practice a kind of knowledge and understanding; often referred to as the authority of the communities on arts, buildings, socio and cultural issues; this local knowledge can be either tangible or intangible encompassing local beliefs, ideas and behavior. Local knowledge is a cultural expression that is typical for Indonesia, because it contains the values, ethics, norms, rules and skills of a community in meeting sustainability challenges of life. In education the contribution of local wisdom lies in all educational activity.

To become individuals capable of society needed three socialization process. These three processes are interrelated to one another. The socialization process is described by Hurlock (2004), as follows

a. Learning to behave in a way that is socially acceptable

b. Learning to play a social role in the community

c. Developing social attitudes or behavior towards other individuals and social activities in the community

Bases on three of the socialization process, therefore learning in early-childhood education must have a function

a. Developing the full potential of children in accordance with their development stage

b. Introducing children to the world around

c. Developing socialization of children

d. Introducing regulations and instill discipline in children

e. Providing opportunities for children to enjoy playing

Ultimately what the objectives of earlychildhood education can be realized. Alwasilah (2009, p. 51) characterizes the local wisdom:

1. Based on experience

2. Tested once used for centuries

3. Can adapt to world culture

4. Mix the daily business community and institutions

5. Commonly used by individuals and society as a whole

6. Characteristically dynamic and constantly changing

7. It is related to the belief system
Furthermore Geerzt (1973, p. 26), explains that "local knowledge is a crucial entity for human dignity in the community. That means the local wisdom that contains the element of intelligence, creativity and knowledge of the local elites and society is to determine the development of civilization". Other voices emerge from UNESCO, (2008, p. 11) "Traditional cultures were more attentive to the rhythm of the environment and careful not to overexploit the natural resources for their survival and co-habitation in the vast ecosystem; they were more rooted in family networks and immediate communities, whereby they provided mutual support to each other."

Local wisdom contains the good of life, so that this principle is a tradition and is strongly attached to local community life. Although there are differences in the character and intensity of social and cultural relations, but in the long term they are bound in the same vision in creating a dignified and prosperous life together. In the frame of this local knowledge, between individuals, between groups complement each other, unite and interact with maintaining values and social norms that apply, so no need to worry in the face the brunt of globalization and become a shield to fend off the attacks of globalization that began to erode the local culture.

\subsection{Learning Strategy}

The education needs to be driven in a planned and purposeful culture gave birth to human beings who are aware, educated, and qualified (Tilaar 2012, p. 98). Furthermore Yusuf (2001) described some social behaviors that are expected to emerge in the preschool or commonly classified into aspects of the ability to build relationships with others, is

1. Child is able to accept the other person's perspective

2. Children have the empathy or sensitivity to the feelings of others

3. Children is able to listen to others

4. Children have the ability to start a relationship with someone else

5. Children can resolve conflicts with others

6. Children have a friendly attitude or easy to get along with their peers

7. Children have an attitude of tolerance and concern for others

8. A child can pay attention to social interests such as: mutual help, work together, live in harmony, sharing and democratic in the mix. So what the objectives of early-childhood education can materialize, the important thing is 
characteristic for early-childhood learning by (Hasan

2011, p. 18)

1. Play and learn

2. Learning orientation on development or multiculturalism to succeed in the earlychildhood classroom the onus seems to fall.

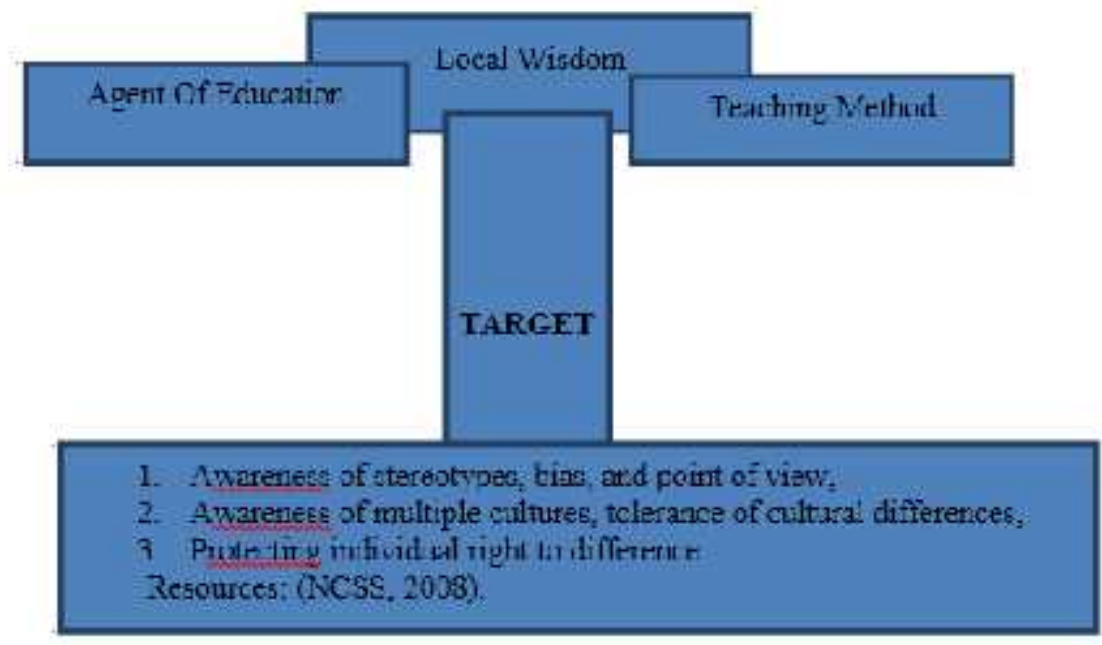

Figure 1. Learning Strategy

Tradition contains noble values sourced from the view of human life. This tradition has a lot of content value for the benefit of human life both in the life of the past, present and future. These values are formed from past civilizations that be a lesson for present-day life. A heritage that can be learned today is one local wisdom (Kurniawati, 2013, p. 535 ). The value of local knowledge is a relic of a past civilization which is expected to be revitalizing to make a young generation. Value, morals, habits, customs / traditions, and a certain culture into the everyday people are things that need to be known and studied by students (Tilaar, 2012, p. 93). In education the contribution of local wisdom lies in all educational activity.

\section{CONCLUSIONS}

Globalization is as a whole negative or positive. It depends on when, where, how and for whom it is assessed, but some studies have shown a definite impact of globalization is weakening the nation's identity. In social culture and geography of the Indonesian state was faced with two important facts, first regarding pluralism in Indonesia and that both effects of globalization. Two facts are otherwise treat properly will bring Net- generation, wrong generalization about pluralism and losing identity. An understanding of cultural diversity or multicultural needs to be owned all community members to avoid conflicts that might occur as a result of the differences that exist. What can be done is to infuse multicultural education coupled with local knowledge (local wisdom).

In addition to creating individual who has the character of each tribe culture, maintain and develop it, and simultaneously build Indonesia with Indonesian culture, so it can become a shield to fend off the attacks of globalization that began to erode the local culture. The atmosphere of the school must be prepared to support this issue

\section{REFERENCES}

Banks, James A., Banks, Cherry .McGee. (2010). Multicultural education, issues and perspectives. Hoboken, USA: John Wiley and Sons, Inc

Geerz, Clifford (1973) the Interpretation of Cultures: Selected Essays. New York.

Hasan, Maemunah (2011) Pendidikan Anak Usia Dini. Penerbit Yogjakarta. Familia Hasan

Hernawan, Asep Herry dkk, (2007) Belajar dan Pembelajaran SD. Bandung: UPI Press.

Hurlock, E. (2004). Psikologi Perkembangan. Jakarta: PT Gramedia Pustaka

Kurniawati, Susanti dan Neta Budiwati (2013) Implementating of Local Wisdom Values to 
Improve Learning Effectivitivness. Prosiding International Seminar Strengthening Social Studies for the Wtenty First Century. Bandung PPS IPS UPI

Muhibbin Syah, (2014),Psikologi Pendidikan dengan Pendekatan Baru,. Bandung: PT Remaja Rosdakarya

Mursid (2016) Pengembangan Pembelajaran Paud Penerbit PT. Remaja Rosdakarya

NCSS. (2003). Social studies definition. Diambil pada tanggal 22Juli 2016 dari http://faculty.plattsburgh.edu/susan.mody/432 SumB04/NCSSdef.htm

Sumaatmadja, Nursid. (2001). Metode Pembelajaran Geografi. Bumi Aksara. Jakarta

Omar, Asmah (2006) the Genius of Malay Civilizasation. Institute of Malay Civilization, UniversitiPendidikan Sultan Idris: Tanjung Malim

Papalia, E, Diane et al. (2009) Human Development, edisi 10. terj. Brian Marsendy. Jakarta: Salemba Humanika.

Solehudin. (1997). Konsep Dasar Pendidikan Prasekolah.Bandung: FIPUPI.

Suyadi dan Maulidya Ulfah (2015) Konsep Dasar PAUD. Penerbit. Remaja Rosdakarya

Tilaar (2012) Perubahan Sosial dan Pendidikan Pengantar Pedagogik Transformatif untuk Indonesia.Penerbit Rineka Cipta

UNESCO, 2008: the Contribution of EarlyChildhood education to sustainable society. Paris: UNESCO

Sujiono, Yuliani Nurani. (2009). Konsep Dasar Pendidikan Anak Usia Dini,Jakarta : PT Indeks

Yusuf, Syamsu. (2001). Psikologi Perkembangan Remaja. Bandung: Rosda Karya 